European Journal of Accounting, Auditing and Finance Research

Vol.10, No. 2, pp.31-51, 2022

Print ISSN: 2053-4086(Print),

Online ISSN: 2053-4094(Online)

\title{
ENVIRONMENTAL DISCLOSURE AND FINANCIAL PERFORMANCE OF LISTED NON-FINANCIAL COMPANIES IN NIGERIA
}

\author{
${ }^{1}$ Junaidu Muhammad Kurawa and ${ }^{2}$ Kabiru Shuaibu \\ ${ }^{1}$ Department of Accounting \\ Faculty of Management Sciences \\ Bayero University, Kano \\ ${ }^{2}$ Department of Accounting \\ Faculty of Arts and Social Sciences \\ Gombe State University
}

\begin{abstract}
Citation: Junaidu Muhammad Kurawa and Kabiru Shuaibu (2022)Environmental Disclosure and Financial Performance of Listed Non-Financial Companies in Nigeria, European Journal of Accounting, Auditing and Finance Research, Vol.10, No. 2, pp.31-51
\end{abstract}

ABSTRACT: This study examines the influence of environmental disclosure (ED) on financial performance of listed non-financial companies in Nigeria from 2013-2020. A sample of seventysix (76) companies listed as non-financial was drawn from the population of one hundred and thirteen (113) companies. Audited annual reports and accounts were used for data extraction. The analysis was done using descriptive statistics and multiple regressions. Explanatory research designed was adopted in the study to find out the influence of ED on financial performance. Variables used include the ED measured using ordinal coding scheme based on GRI guidelines (G4) focusing on environmental prevention expenditure disclosure(EN40), Waste disposal, emission treatment and remediation cost disclosure (EN41), Prevention and environmental management cost disclosure (EN 41) used as proxies for independent variable and financial performances' accounting and market based measures proxy by earnings per share and Tobin's $Q$ was used as the dependent variable. Robustness tests such as multicollonearity test, heteroscedasticity test, normality test and Hausman specification test were conducted to validate the results. The study revealed that there is positive significant relationship between EPED, $W D C D, P M C D$ and EPS while negative with TQ of listed Nigerian non-financial companies. The study therefore, recommends that the management of listed non-financial companies in Nigeria should create awareness on the importance of EPED, WDCD, PMCD and the other benefit that can be derived by a company and investors as a result of engaging in environmental activities as this may create good relationship between the company and the environment and consequently will improve financial performance. And also professional accounting bodies in Nigeria like the ICAN and the ANAN should key into introducing environmental and sustainability reporting into their mandatory professional education programs as this is a contemporary issue in accounting development this will help accountants to be trained on environmental accounting and reporting.

KEYWORDS: environmental disclosure, EPS, Tobin's Q, firm size, firm leverage, board size

ECRTD-UK: https://www.eajournals.org/

Journal level DOI: https://doi.org/10.37745/ejaafr.2013 


\section{INTRODUCTION}

No any forms of business weather big or small, private or public, profit making or non- profit making organizations exists in a vacuum or operate in a closed system without any form of interaction with the environment. Business operations effects the environment and caused some devastating issues to the environment such as climate change, global warming and pollution. The aforementioned issues have caused public concern and awareness about the hazardous operations of these companies to the host community and as a result of the public awareness companies are expected to show commitment toward environmental policies and the need for disclosure of environmental information in their annual and sustainability reports and disclosure of environmental information by companies seems to be even more important from the context of developing countries like Nigeria.

The operations of corporate sector activities in Nigeria has resulted in the massive environmental pollution in the country. Nigeria has been identified as one of such country, with a high level of environmental pollution that contributes significantly to global environmental problems that result to global warming, climate change, pollution, oil spills, gas flaring and deforestation. Oil spills in Nigeria have been regular occurrence, and the resultant degradation of the surrounding environment has caused significant tension between the people living in the region and the multinational oil companies operating in those areas. For instance, a UNEP report (2011) shows that Shell which is one of the oil producing companies in the country that has been contributing to environmental degradation in the oil region of Niger delta. It was evident that environmental pollution has caused great damage to the oil areas, affects their main source of economy and subsequently introduced devastating acid rain to the land of the oil producing communities. As the extent of environmental impacts in the country became clear, and in particular those in the Niger Delta region, so social and political unrest grew with the breeding of 'militancy activities' amongst people in particular the youth who attacked, kidnapped, vandalized oil pipes and killed the workers of oil companies.

Further evidence showed that in some part of Nigeria, even life expectancy has been threatened by the environmental hazards from oil exploration. According to UN report in 2008 the life expectancy in the Niger Delta is 44.7 years for men and 46 for women while in other parts of the country is higher, 46.76 for men and 48 for women (CIA World fact book 2011). However, for the fact that less attention is given to the negative impacts of environmental pollution from the activities of non-financial companies thus, this call for research in this area (environmental disclosure) in Nigeria.

The constitution of the federal republic of Nigeria recognizes the importance of improving and protecting the air, land, water, forest and wildlife in the country, the constitution of Nigeria makes provision for this through relevant sections of the constitution which include: Section 12 and Section 2. On the other hand, the national environment standards and regulation enforcement agency (NESREA) Act of 2007 which replaced the federal environmental protection agency

ECRTD-UK: https://www.eajournals.org/

Journal level DOI: https://doi.org/10.37745/ejaafr.2013 
(FEPA) Act; is a pool of laws and regulations aimed at protecting and sustaining the development of the environment and its natural resources.

Moreover, environmental impact assessment (EIA) Act, 2004, is an assessment of the potential impacts of a proposed project on the natural environment. The laws of the federal republic of Nigeria 1992 Decree No.82 on environmental impact assessment require that companies before embarking on any activity that has effect on environment, to submit environmental impact assessment policy. The policy includes among others the following information; the description of the activities, description of the potentially affected environment, assessment of potential environmental impacts on proposed activity.

The introduction of various independent bodies such as global reporting initiative (GRI), business in the community (BITC) in the year 2000 proposed some certain guidelines to social, environmental and financial reporting that companies should follow as a guide in disclosing their environmental information. The global reporting initiative (GRI) is a non-profit organization that promotes economic, environmental and social sustainability and provides all companies and organizations with a comprehensive sustainability reporting framework that is widely used around the world. The first version of the guidelines, G1 was launched in year 2000. Subsequently, others followed; G2 (2002); G3 (2006), with updated and complete version (G3.1) in 2011. The G4 was launched in 2013. This study creates a scorecard which is based on those principles described in GRI (4) guidelines focusing on environmental prevention expenditure disclosure(EPED), Waste disposal, emission treatment and remediation cost disclosure (WDCD), Prevention and environmental management cost disclosure (PMCD).

It can be deduced that there is need for companies to engage fully in activities that will improve the well-being of their host communities and the society in general and such activities should be reported and disclosed so that the society will know the extent and the level of the companies' commitment toward environment. The disclosure of such information may have impact on the financial performance of the companies involved because ED suggests that a good relationship with employees, suppliers and customers are necessary for the survival of the company and when a company increases its cost by improving ED in order to increase competitive advantages, such ED activities can enhance company reputation, decreasing the level of information asymmetry between a firm and its investors, thus lowering firm risk and increasing financial performance in the long run.

Several different arguments have been advanced as how ED effects financial performance of companies which is basically divided into two schools of thought namely; the cost concerned school and the value-creation school. The cost concern school argues that environmental investment and high ED represent only increased cost, resulting in decreased earnings and lower value. On the other hand, the value creation school viewed environmental reporting and commitment as a means of increasing competitive advantage, trust between the host community and the companies, sales and these lead to increase in financial performance.

ECRTD-UK: https://www.eajournals.org/

Journal level DOI: https://doi.org/10.37745/ejaafr.2013 
The Niger delta region in Nigeria is one of the top most polluted spots on earth with $2.5 \mathrm{BCF}$ of gas flared daily, and with over 2,000,000 tons of oil spilled to date and over $70 \%$ of the oil spill still uncovered that lead to kidnapped and killing of the workers of oil companies, vandalized oil pipes, bombing of Government and companies' establishment and payment of ransom by multinationals are some of the socio-physical events emanating from such damages caused by operations of these companies to the environment (Ironkwe and promise, 2016).

This study perhaps differs from previous studies on an important aspect, the measurement of ED level, other researches such as that of Oba and Fodio (2012), Bassey, Effiok and Eton ,(2013), Makori and Jango, (2013), Namakonzi and Inanga, (2014), Adekanmi ,adedoyin, and adewole, (2015), Dibia and Onwuchekwu, (2015); Ong, Tho, Goh, Thai and Tech, (2016); Jeroh and Okoro, (2016); Agbiogwu, Ihendinihu and Okafor, (2016); Ezejiofor,Racheal and Chigbo, (2016); Eze, Nweze and Enekwe, (2016); Nnamani, Onyekwelu, and Ugwu , (2017); Ezeagba, Racheal, and Chiamaka, (2017); Ebonike and Okoro, (2018); Shuaibu, Muhammad and Isah, (2019) measured the level of disclosure by counting, for example, the number of words, sentences or pages in the annual report and high/low disclosure rating where a value of 1 assigned for disclosure of environmental information and a score of 0 for non-disclosure, after this, the relation between specific variables and the amount of disclosures are tested. Applying this measurement tool, questions can be raised because ED differs across companies due to variation in writing style, page and type size. In terms of disclosure practices, it is noteworthy that mere quantity of disclosures is insufficient for signaling facts about environmental strategies however, volume alone cannot be sufficient enough to analyze companies' commitment to environmental practices and this study adopted a scale of 0-3 such that if there is no disclosure on environmental indicator 0 is scored, however, if there is disclosure without any resemblance to GRI guidelines, 1 is scored, if disclosure is partially consistent with GRI guideline 2 is scored while if disclosure is fully consistent with GRI guideline, 3 is scored. So therefore, it is more interesting to examine measures in terms of quality which is the concern of the current study. In light of the foregoing the following research questions are raised;

i. What is the impact of EPED on the financial performance of listed non-financial listed companies in Nigeria?

ii. How does WCDC impact on the financial performance of listed non-financial companies in Nigeria?

iii. To what extent does PMCD impact on the financial performance of listed non-financial companies in Nigeria?

The remainder of the paper is organized as follows: Section two (2) provides literature on ED and financial performance Section three (3) presents methodology of the study. Section four (4) Presents results and discussions and lastly section five (5) discusses conclusions and recommendations.

ECRTD-UK: https://www.eajournals.org/

Journal level DOI: https://doi.org/10.37745/ejaafr.2013 


\section{LITERATURE REVIEW}

\section{The Concept of ED}

Ong, Tho, Goh, Thai and Teh (2016) viewed ED as a planned statement that depicts company's environmental burden and environmental efforts including company's objectives, environmental policies, environmental activities and impacts, reported and published periodically to the public. ED as defined by Olayinka and Oluwamayuwa, (2014) is the umbrella term that depicts different ways that companies disclose information about their environmental activities to various users of financial statement. According to this study ED refers to self-reporting of firms' environmental impact information to stakeholders that serves as a medium of communication between the company and its stakeholder. The disclosure of this information is done in a variety of different forms and medium depending on the organizations and the countries where the companies are located.

\section{Concept of Financial Performance}

The subject of corporate performance has received significant attention from scholars in the various areas of business and accounting. Financial performance is a gauge to express the general financial productivity of an organization over a span of financial period and aids in comparison of financial results of other firms in the same sector (Jat, 2006). There are two main categories concerning the measurement of the financial performance of a company: Accounting-based measures and market-based measures. The accounting-based measures refer to indicators such as sales growth, return on asset, return on equity, return on capital employed, earnings per share and others, whereby the market-based measures include different forms of stock market and shareholder returns, Tobin's Q and many more (Pandy, 2005).

Therefore, this paper focused on both accounting and market based measures of financial performance using earnings per share and Tobin's Q to find out the impact of ED on both operating performance(EPS) and future performance(TQ) of listed non-financial companies in Nigeria.

\section{Empirical Review}

There has been a wealth of research studies on the various outcomes of ED and financial performance. Some studies found positive relationship between ED and financial performance and other studies found negative while others found no relationship between ED and financial performance. The following are the studies reviewed;

Igbekoyi, Ogungbade and Olaleye (2021) assess the relationship between environmental reporting practices and financial performance of listed manufacturing companies in Nigeria. The study employed ex-post facto research design and made use of secondary data sourced from annual reports and accounts of sampled firms. A total of 23 firms were selected from 67 manufacturing firms quoted as at December, 2018 financial year ended where by twenty-three firms (23) which represent $30 \%$ of the population were proportionally selected from the stratified sector to ensure each sub-sector have equal chance of being represented in proportion of their sizes. The period covered by the study was 11 years (2008 to 2018). The environmental sustainability reporting

ECRTD-UK: https://www.eajournals.org/ 
practices was measured using ordinal binary scheme where 3 point was assigned if there is a separate disclosure score, if it's in the chairman statement 2 and if it's in the footnotes to financial statement 1 and if not disclosed, the firm scored 0 and financial performance was represented by profitability and liquidity using profit after tax, earnings per share and liquidity ratio. The result of the analysis showed that profit after tax as proxy for profitability has a positive significant effect on environmental sustainability reporting practices of quoted manufacturing firms while earnings per share has a positive relationship but insignificant effect on environmental sustainability reporting. The result for liquidity ratio shows negative and insignificant relationship with environmental sustainability reporting.

On the other hand, in a study conducted by Dhar and Ashraful (2021) that examine the effect of environmental accounting reporting (EAR) practices on the financial performance of the banking industry of Bangladesh. Panel data consisting of 25 listed banks in Dhaka Stock Exchange (DSE) over the period 2012 to 2016 has been employed in this study. An environmental accounting reporting score (EARS) index has been developed by analyzing the content of banks' annual reports where 1 was assigned for disclosure of environmental information and 0 for non-disclosure of environmental information and for the dependent variable (financial performance) was proxy by return on asset (ROA), return on equity (ROE), Earnings per share (EPS) and profit margin (PM) and the study controlled for size, capital ratio, loan ratio, overhead expense ratio and debt ratio. Using Pooled OLS, the analysis revealed that EAR reporting had been increased after publishing the Bangladesh bank guideline. The empirical analysis showed that a significant positive correlation between EAR and profit margin (PM). However, EAR has an insignificant relationship with ROAE (return on average equity), EPS (earnings per share), and ROAA (return on average assets). Among control variables, size, capital ratio, overhead expense, and loan ratio have a significant impact on financial performance.

In addition, Pedron, Clea and Simon, (2021) examines the relationship between ED effects on returns and market value of listed Brazilian Companies. The environmental disclosure was measured using content analysis of audited annual reports and accounts of the sampled companies and for the dependent variable is financial performance proxy by ROA and Tobin's Q for the period of 2010-2019. The study used binary coding scheme to measure ED where 1 and 0 was assigned for the presence and absence of EI in the audited annual reports and accounts of the sampled companies. The study used explanatory research design to explain the relationship between ED and financial performance of companies listed in Brazil stock exchange. The study employed legitimacy theory and proprietary costs theory to explaining part of the decision process regarding the disclosure of environmental information. The regression results from the analysis shows that ED has a significant positive impact on financial performance as measured by ROA and Tobin's Q.

Moreover, in order to determine the relationship between social and ED and firm's performance of non-financial firms in Nigeria, Emeka, Nwezu and Nwadiolor (2020) adopted ex-post facto research design and financial data for the study from the entire 107 non-financial firms with data spanning from the period of 2011-2018. The variables used are CSRD, ED and net asset per share

ECRTD-UK: https://www.eajournals.org/

Journal level DOI: https://doi.org/10.37745/ejaafr.2013 
and the statistical test of parameter estimates was conducted using panel regression model. The findings generally indicate that corporate social and environmental disclosures have significantly influenced firms' performance at 5\% significant level. In Kenya, Wara, Magali and Mohamed (2020) investigate the impact of ED on financial performance of companies listed on the Nairobi Stock Exchange. The population of the study was made up of all the companies listed on the Nairobi Securities Exchange (NSE) making 64 companies and census sampling was adopted. ED information was collected using quantitative content analysis for the period 2007-2015 while financial performance data was collected for the period 2008-2016, a one-year lag behind the environmental disclosure data. Control variables were firm size, industry type and leverage. Environmental disclosure was found to be statistically significantly positively related to the firms' return on assets but not statistically significant with return on equity and Tobin's Q.

Similarly, in Nigerian scene, Iliemena (2020) analyze the relationship between environmental accounting practices and corporate performance of listed oil and gas companies. Ex-post facto research design was employed in the study and the analysis carried out using simple linear regression. Data obtained from stock exchange fact books, corporate sustainability reports and annual reports of sample firms for the period of 2012- 2018 and Ex-post facto research design was employed in the study. The population of the study is made up of ten (10) oil and gas companies which are listed on the Nigerian Stock Exchange as at 17th July 2019. Variables used for environmental accounting include material accounting, energy accounting, environmental compliance accounting and for corporate performance include change in turn over, return on capital employed, net profit percentage. Findings reveal environmental accounting practices and accounting have significant positive effects on both turnover and Return on capital employed; while the effect on net profit even though positive, was insignificant. These results indicate that as companies practice environmental accounting and reporting, their profitability level begins to increase owing to increase in reputation which yields increase in sales revenue and returns.

Furthermore, Moshud (2020) focused on assessing the impact of profitability on ED of quoted firms in Nigeria. The research has been undertaken on all companies listed in the Nigeria Stock Exchange (NSE). The study adopts a cross-sectional research design. The study used a sample of 82 firms from the total population of 176 firms listed on the Nigeria Stock Exchange for a period of 5 years ranging from 2012 to 2016. Method of data collection was secondary data. The study employed Binary regression logistic techniques as the method of data analysis where 1 and 0 was recorded for ED. The findings of the study indicate that a significant relationship exists between profitability and ED. The study therefore concludes that firm voluntarily discloses the effect of their operations on the environment they operate. The implication of the findings is that though the study revealed that there is a significant relationship between ED and Profitability, it should be noted that in event of companies incurring losses, it will have effect on ED. This study considered the volume of EI where by the current study focused on the quality of EI disclosed by non-financial companies in Nigeria.

ECRTD-UK: https://www.eajournals.org/

Journal level DOI: https://doi.org/10.37745/ejaafr.2013 
In contribute to the debate, a weighted disclosure index was used by Nguyen and Tran (2019) in assessing the relationship between disclosure levels of environmental accounting information and financial performance of firm listed in Vietnam. Data were collected from the firm's annual report and accounts from 2013 to 2017 by using multivariate regression models to investigate the relationship between environmental accounting information and financial performance (return on assets and Tobin's Q). The results indicate that there was a close relationship between disclosure level of environmental accounting information and financial performance. In addition, there was a difference in terms of financial performance between the firms that did not disclosed environmental accounting information and the firms that disclosed the environmental accounting information.

Lastly, in a study conducted by Emmanuel, Elvis and Abiola (2019) analyze the effect of environmental accounting disclosure on firm value of listed industrial goods companies in Nigeria from 2007- 2016. The data for the study were gathered through the annual financial statement of the companies through using multiple regression was used to analyze the effect of environmental accounting disclosure on firm value. Environmental accounting disclosure was measured by nonfinancial indicators, financial indicators and performance indicators while the firm value represented by Tobin's Q. From the result, it is evident that non-financial indicators (environmental disclosure) have a positive significant effect on firm value while performance indicators (environmental disclosure) have a negative significant effect on firm value and the financial indicator (environmental disclosure) has no significant effect on firm value of industrial goods companies in Nigeria.

It can be deduced that from the findings of the above studies that there is a growing interest in researching about ED and financial performance. It can be deduced that the findings show mixed results (positive, negative and no relationship). The reasons for the failure to reach a consensus regarding the implications of ED measurement, given the absence of clear mandatory guidelines as to what firms should report in terms of their information about their environment, how studies measure ED in this area varies differently. Therefore, different formats, content or approaches are used to ED and companies tends to disclose in different formats as most of the studies above measured ED using binary coding scheme focusing on the quantity of environmental information disclosed. Therefore, this paper focused on the quality of the information disclosed by nonfinancial companies listed on the NSE using ordinal coding scheme.

ECRTD-UK: https://www.eajournals.org/

Journal level DOI: https://doi.org/10.37745/ejaafr.2013 


\section{Theoretical Background}

This study employs an institutional theory perspective in examining the impact of environmental disclosure on the financial performance of listed non-financial companies in Nigeria. Institutional theory views organizations as operating in a social framework of rules, norms, values and routines of what constitutes appropriate behavior. Scott (1995) argues that in order to survive organizations must conform to current beliefs and norms in the environment. It can be deduced that when organization disclosed information relating to the environment, these serves as transparency and accountability and it may increase the organization's reputation and image in the eye of the public and it may lead to increases in sales and in the long run financial performance may increase.

\section{METHODOLOGY}

The study adopted explanatory research design in order to examine the impact of ED on financial performance of listed non-financial companies in Nigeria by observing the variation in ED that may cause to a change in financial performance. Data were obtained from annual report and account of the sampled companies as well as the fact book of Nigerian Stock Exchange for the period of eight years (2013 to 2020). This is because the GRI was introduced in 2013 which is the index used by the study. The population of this study comprised of all the non-financial companies listed on the Nigerian Stock Exchange (NSE) as at $31^{\text {st }}$ December, 2020, this is because nonfinancial services companies are more environmentally sensitive companies and their operations are more hazardous when compared to that of financial companies. There are one hundred and thirteen (113) non-financial companies listed on NSE as at $31^{\text {st }}$, December, 2020. The companies are categorized into ten (10) sub-sectors namely; Agriculture, Conglomerates, Construction, Consumer goods, Health care, ICT, Industrial, Natural resources, Oil and gas and Services companies. This study employed census sampling technique where all members of the population are to be considered but due to some limitation the following filters are applied.

i. $\quad$ Companies must be listed on or before 2013 because the time scope of the study is from 2013 to 2020.

ii. Companies must have complete data for the study period thus; seventy-six (76) companies met the requirements and are the sample size of the study.

\section{Variables of the Study and their Measurement}

The means by which the various variables adopted in this study are measured or computed are shown in Table 3.1

ECRTD-UK: https://www.eajournals.org/

Journal level DOI: https://doi.org/10.37745/ejaafr.2013 
European Journal of Accounting, Auditing and Finance Research

Vol.10, No. 2, pp.31-51, 2022

Print ISSN: 2053-4086(Print),

Online ISSN: 2053-4094(Online)

Table 3.1: Variables of the Study and their Measurement

\begin{tabular}{|c|c|c|}
\hline Variables & Abbreviation & Measurement \\
\hline \multicolumn{3}{|l|}{ Dependent Variable } \\
\hline Financial performance & $\begin{array}{l}\text { EPS } \\
\text { TQ }\end{array}$ & $\begin{array}{l}\text { Net profit after tax divided by outstanding shares as used by } \\
\text { igbekoyi, et.al (2021). } \\
\text { Market value of shares divided by book value of shares as used by } \\
\text { Nguyen and Tran, (2019). }\end{array}$ \\
\hline \multicolumn{3}{|l|}{ Independent Variable } \\
\hline $\begin{array}{l}\text { Environmental protection } \\
\text { expenditure disclosure }\end{array}$ & EPED & $\begin{array}{l}\text { When the EI is fully in compliance with GRI } \\
\text { When the EI is nartially in compliance with GRI }\end{array}$ \\
\hline $\begin{array}{l}\text { Waste disposal, emission } \\
\text { treatment and remediation } \\
\text { cost disclosure }\end{array}$ & WDCD & Presence of EI not in compliance with GRI \\
\hline $\begin{array}{lr}\text { Prevention } & \text { and } \\
\text { environmental } & \text { management } \\
\text { cost disclosure } & \end{array}$ & PMCD & $\begin{array}{l}\text { No environmental information disclosure as used by } \\
\text { Mohammad, et.al,(2020). }\end{array}$ \\
\hline \multicolumn{3}{|l|}{ Control Variables } \\
\hline Leverage & LEV & $\begin{array}{l}\text { Leverage is measured as the Total debt divided by total asset as } \\
\text { used by Okpala and Iredele, (2018). }\end{array}$ \\
\hline Board Size & BSIZE & $\begin{array}{l}\text { Total number of directors on the board of the organization as used } \\
\text { by Okpala, and Iredele, (2018). }\end{array}$ \\
\hline Firm Size & FSIZE & Natural Log of total asset as used by Emeka and Okeke, (2019). \\
\hline
\end{tabular}

Source: Generated by the Researcher from Empirical Literature, 2021

\section{Model Specification}

The model for this variable will estimates the effect of ED and financial performance which is a modification of Nguyen and Tran (2019).

$\mathrm{EPS}_{\mathrm{it}}=\alpha_{0}+\beta_{1} \mathrm{EPED}_{\mathrm{it}}+\beta_{2} \mathrm{WDCD}+\beta_{3} \mathrm{PMCD}_{\mathrm{it}}+\beta_{4} \mathrm{LEVit}+\beta_{5} \mathrm{BSIZE}_{\mathrm{it}}+\beta_{6} \mathrm{FS}_{\mathrm{it}}+\varepsilon_{\mathrm{it}} \ldots$ (i)

$\mathrm{TQ}_{\mathrm{it}}=\alpha_{0}+\beta_{1} \mathrm{EPED}_{\mathrm{it}}+\beta_{2} \mathrm{WDCD}+\beta_{3} \mathrm{PMCD}_{\mathrm{it}}+\beta_{4} \mathrm{LEVit}+\beta_{5} \mathrm{BSIZE}_{\mathrm{it}}+\beta_{6} \mathrm{FS}_{\mathrm{it}}+\varepsilon_{\mathrm{it}} \ldots$. (ii)

Where;

EPS= Earnings per Share

$\mathrm{TQ}=$ Tobin's $\mathrm{Q}$

EPED = Environmental Prevention Expenditure Disclosure

WDCD $=$ Waste disposal, emission treatment and remediation cost disclosure

$\mathrm{PMCD}=$ Prevention and environmental management cost disclosure

LEV = Leverage

BSIZE $=$ Board Size

FSIZE $=$ Firm Size

$\alpha=$ Constant Term

$\beta=$ Coefficient Term

$\mathrm{i}=$ No of firms

$\mathrm{t}=$ Time Period

$\mathrm{e}=$ Error term

ECRTD-UK: https://www.eajournals.org/

Journal level DOI: https://doi.org/10.37745/ejaafr.2013 


\section{RESULTS AND DISCUSSIONS}

This section presents the results of the analysis of the collected data from the annual report and accounts of the sampled non-financial listed companies in Nigeria. The descriptive statistics, correlation and regression analysis are presented below.

\section{Diagnostic Test of Independent and Dependent Variables}

To check and improve the validity and reliability of the data, diagnostic tests has been conducted such as multicollinearity, heteroskedasticity, hausman specification tests.

Table 4.1: Diagnostic Test

\begin{tabular}{lccc}
\hline Model Multicollinearity VIF test & Heteroskadasticity test & Hausman test \\
\hline 1. & 1.08 & 0.0000 & 0.1542 \\
2. & 1.08 & 0.0000 & 0.0001 \\
\hline
\end{tabular}

Source: Generated by the researcher from the Annual Reports and Account of the sampled companies using STATA 16.0

The result in Table 4.1 shows the absence of multicollinearity as the variance inflation factor (VIF), test value is less than 5 in all the model of the study. The mean of the entire VIF test in all the model ranges from 1.08 to 1.08 which proved that is less than 10 and there is absence of multicollinearity. The table also reveals the presence of heteroscedasticity in the ordinary least squares regression results of the models 1 and $2(0.000$ and 0.000$)$ respectively and this indicates that the variability of error terms is not constant and this can affect inferences in respect of beta coefficient, coefficient of determination (R2), t-statistics and F-statistics of the study. Furthermore, the table reveals p-value of 0.1542 and 0.0001 for model 1 and 2 respectively. This means that random effects is more efficient for model 1 as the p-value is greater than 5 and for model 2 fixed effect is more efficient as the p-value of the model in the study is significant i.e less than $5 \%$ but the heteroscedasticity shows that coefficient of the error term is not constant for the explanatory variables; therefore, the study corrected this by applying the Panel Corrected Standard Error Regression (PCSEs) for the models. And also the data for the Tobin's Q, the result indicate presence of outliers and this suggest data transformation to be carried out to eliminate the outliners and therefore, the data for Tobin's Q has been transformed to the natural $\log$.

Table 4.2: Descriptive statistics result

\begin{tabular}{|l|l|l|l|l|l|}
\hline Variables & Obs & Mean & Std. Dev & Min & Max \\
\hline EPS & 608 & 3.112968 & 8.683087 & -22 & 57.63 \\
\hline TQ & 608 & 0.5011926 & 0.5115956 & 0.000144 & 7.0672 \\
\hline EPED & 608 & 1.161184 & 0.9023162 & 0 & 3 \\
\hline WDCD & 608 & 0.2648026 & 0.4669766 & 0 & 2 \\
\hline PMCD & 608 & 0.3569079 & 0.489681 & 0 & 2 \\
\hline LEV & 608 & 1.328812 & 5.888958 & 0.000372 & 87.72046 \\
\hline BSIZE & 608 & 9.288303 & 2.776774 & 4 & 23 \\
\hline FSIZE & 608 & 10.13637 & 0.8341442 & 7.680181 & 12.86309 \\
\hline
\end{tabular}

Source: Generated by the researcher from the Annual Reports and Account of the sampled companies using STATA 16.0

ECRTD-UK: https://www.eajournals.org/

Journal level DOI: https://doi.org/10.37745/ejaafr.2013 
Table 4.2 shows the descriptive statistics of financial performance (EPS and TQ) and environmental disclosure (EPED, WDCD and PMCD) as well as those of the control variables leverage (LEV), board size (BSIZE), firm size (FSIZE). The table also shows that the number of observations for each variable is 608 . This represents the 76 sampled companies with the study period of 8 years. The result shows that EPS has a mean of 3.11 with standard deviation of 8.68, minimum and maximum of -22 and 57 respectively, whereby TQ has a mean of 0.50 with standard deviation of 0.511 and minimum and maximum value of 0.00 and 7.06 respectively. The EPED has a mean of 1.16 with a standard deviation of 0.902 indicating that there is high variation among the data with a minimum value of 0 and maximum 3 showing that the level of ED among nonfinancial companies differs in significantly during the study period. The second component of ED (WDCD) shows a mean of 0.264 and a minimum and maximum value of 0 and 2 respectively. The last component of the ED (PMCD) shows a mean of 0.356 with a standard deviation of 0.489 alongside minimum and maximum value of 0 and 2 respectively.

The control variables used in the study showed the mean of LEV is 1.32 and a standard deviation of 5.88 with minimum value indicated as .0 .000 and the maximum value of 87.7 means that the level of LEV among the sampled companies differs significantly during the study period. The BSIZE shows a mean value of 9.28 with a standard deviation of 2.77 and a minimum and maximum value of 4 and 23 respectively indicating that the board of firms in non-financial sector differs significantly in size during the study period. The FSIZE has a mean value of 10.13 and a standard deviation of 0.834 respectively. The minimum value and maximum value of the size of the firm during the study period were 7.68 and 12.86 indicating that the size of the firm during the study period does not differs significantly.

Table 4.3: Correlation Matrix of the Independent and dependent Variables

\begin{tabular}{|l|l|l|l|l|l|l|l|l|}
\hline Variables & EPS & TQ & EPED & WDCD & PMCD & LEV & BS & FS \\
\hline EPS & 1.0000 & & & & & & & \\
\hline TQ & -0.2527 & 1.0000 & & & & & & \\
\hline EPED & 0.1131 & -0.0046 & 1.0000 & & & & & \\
\hline WDCD & -0.0739 & -0.0077 & 0.0829 & 1.0000 & & & & \\
\hline PMCD & 0.0649 & -0.0030 & 0.0453 & 0.2535 & 1.0000 & & & \\
\hline LEV & 0.1809 & 0.0381 & 0.0524 & -0.0051 & -0.0268 & 1.0000 & & \\
\hline BSIZE & 0.0487 & -0.1928 & -0.0035 & -0.0435 & 0.0155 & -0.0013 & 1.0000 & \\
\hline FSIZE & 0.3884 & 0.4972 & 0.00323 & -0.0766 & 0.0375 & -0.113 & 0.3320 & 1.0000 \\
\hline
\end{tabular}

Source: Generated by the researcher from the Annual Reports and Account of the sampled companies using STATA 16.0

From table 4.3 the relationship between EPS and EPED with the value of 0.1131 shows a moderate positive correlation. WDCD has a weak negative correlation with EPS with a coefficient of 0.0739. On the other hand, EPS has a positive weak correlation with PMCD a correlation coefficient of 0.0649 . LEV one of the control variables shows a moderate positive relationship with EPS with a coefficients value of 0.1809 while BSIZE shows positive weak relationship with

ECRTD-UK: https://www.eajournals.org/

Journal level DOI: https://doi.org/10.37745/ejaafr.2013 
EPS with a value of 0.0487 and lastly FSIZE documented a coefficient value of 0.3884 indicating a positive relationship with EPS in a stronger direction.

Furthermore, Table 4.3 also documented a negative weak correlation between EPED and TQ with a value of -0. 0046.WDCD has a weak negative correlation with TQ with a coefficient of -0.0077 . On the other hand, TQ has a negative weak correlation with PMCD a correlation coefficient of 0.0030.LEV one of the control variables shows a weak positive relationship with TQ with a coefficients value of 0.0381 while BSIZE shows negative moderate relationship with TQ with a value of -0.1928 and lastly FSIZE documented a coefficient value of -0.4972 indicating a negative relationship with TQ in a moderate manner.

Regression Result on EPED, WDCD, PEMCD and EPS

Table 4.4 presents the PCSEs Regressions result of (Model I).

\begin{tabular}{llcl}
\hline Variables & Coefficients & $\mathbf{z}$ & $\mathbf{p}>/ \mathbf{t} /$ \\
\hline EPED & 0.8593662 & $3.51^{* * * *}$ & 0.000 \\
WDCD & -1.215839 & $-3.12^{* * *}$ & 0.002 \\
PEMCD & 1.191115 & $3.04^{* * *}$ & 0.002 \\
LEV & 0.2273055 & $3.63^{* * *}$ & 0.000 \\
BSIZE & -0.27238 & $-3.87^{* * *}$ & 0.000 \\
FSIZE & 3.45368 & $17.58^{* * * *}$ & 0.000 \\
CONS & -28.44454 & -15.73 & 0.000 \\
& & & \\
R-squared & 0.2255 & & 0.000 \\
P-Value & & &
\end{tabular}

Source: Generated by the researcher from the Annual Reports and Account of the sampled companies using STATA 16.0

NOTE: *,**,*** Indicates significant@ 10\%, 5\% and 1\% respectively

The cumulative adjusted $\mathrm{R}^{2}$ is $22 \%(0.2255)$, which gives cumulative effect of all independents variables jointly on the dependent variable. This means that $22 \%$ of the variation in the EPS is caused by EPED, WDCD, PMCD, LEV, BSIZE and FSIZE while $78 \%$ of the variation in EPS is caused by other factors not considered in the model of the study. This indicates that the model is fit and the explanatory variables are carefully selected considering the p-value of 0.0000 . This implies that when there is change in EPED, PMCD of listed non-financial companies in Nigeria, the EPS will also be affected by the change positively and will be affected negatively by WDCD.

Table 4.4 reveals that EPED and PMCD has a positive and significant impact on EPS at $1 \%$ level of significance while WDCD has a negative and significant impact on EPS at $1 \%$ level of significance. This means that the more companies disclose environmental information regarding EPED and PMCD the higher the EPS of listed non-financial companies in Nigeria under the study period. Evidence shows if EPED and PMCD increases by one unit, financial performance measured using EPS will increase by 0.8593662 and 1.233688 respectively. On the other hand, WDCD has a negative and significant impact on EPS of listed non-financial companies indicating

ECRTD-UK: https://www.eajournals.org/

Journal level DOI: https://doi.org/10.37745/ejaafr.2013 
that when WDCD increases by one unit EPS will decreases by 1.278777 . Therefore, it may be as a result that WDCD by companies is not the main consideration of investors during decision making. Another reason for documenting a negative relationship between WDCD is because the cost involved in taking care of the waste of the firm is high because it involves cover treatment and how waste will be managed, pollution, reparation, resourcing cost, and conservation cost. The finding is in line with the findings of Moshud, (2020) and not in agreement with the findings of Oti and Genaldine, (2018), Adegbie, et.al, (2020).

The result of the study (EPED and PMCD) support the conventional wisdom and stakeholders' theory that advocates that ED increases accountability and good relationship toward a broad range of stakeholders' such as customers, suppliers, employees, Government, environment, community and future generations in maximizing firm's EPS, stakeholder interest should not be ignored i.e. the company must not only maximize economical goal but also stakeholder's goal. The result of this study is in line with the first school of thought of ED and financial performance that viewed ED as a way of increasing competitive advantage and improves financial returns to the investors therefore increases earnings. This finding is consistent with work of Dhar \& Ashaful (2021), Adegbie, et.al, (2020), Polycarb (2019), Oti \& Geraldine, Nwaiwu \& Oluka(2018)Amiolemen,et.al, (2018), Abubakar, Moses \& Inuwa (2017), Nnaemeka, Lucy \& Kevin (2017), Ong, et.al, (2016). However, contradicts the works of Abdullah (2018), Adediran \& Alede (2013), Makori \& Jagongo (2013).

Leverage is found to have positive and significant impact on financial performance measured by EPS at $1 \%$ level of significance. This means that, the more the debt of the listed non-financial companies of Nigeria the higher the EPS and this can be explained in line with the conventional economic theory which advocates that firms with larger leverage have higher financial performance because tax is not paid on such amount borrowed which may in turn lead to higher financial performance. The finding is consistent with the findings of Abubakar, et.al, 2017 However, is contrary to the findings of Okpala and Iredele, (2018).

Board size is found to have negative and significant impact on financial performance measured by EPS at $1 \%$ level of significance of listed non-financial companies in Nigeria. This implies that as board increases in size this would definitely affect EPS negatively. The findings of this study does not support the argument of agency theory that proposes that the board of directors acts as representative of the various groups of shareholders for monitoring the performance and controlling the activities of managers. The result of the study is in line with argument that in larger board there is like hood of slow decision making and higher cost in terms of compensation and incentives which may affect the operating performance of the firm. The result of this study supports the findings in Okpala and Iredele (2018) that higher expenses and poor communication in larger boards make smaller boards preferable for improving financial performance and the result of the study does not agree with the findings of ojeka,et.al, (2014) that having more directors on the board guarantee that more skills diversity, experience will help improve financial performance. The support for the negative relationship focuses more on the time and cost but not on the long term benefits that may be achieved as a result of pool skills and experience.

ECRTD-UK: https://www.eajournals.org/

Journal level DOI: https://doi.org/10.37745/ejaafr.2013 
Firm size shows a positive and significant impact on EPS at $1 \%$ level of significance. This may be in line with the general assumptions that the larger board hold more resources along with strong market power that leads to earning more profits and enjoy the advantages of economies of scale which may enable larger firms to achieve production at a lower cost because of the high level of proper efficient utilization of resources. The result is in line with the study of Uwuigbe (2012); Emeka and Okeke, (2019). The finding is however contrary to the findings of Emeka and Benjamin (2019) that documented a negative relationship between firm size and financial performance of listed non-financial firms in Nigeria. The differences in the findings may be as a result of variance in the methods of obtaining the firm size and the study period.

\section{Hypothesis Testing on EPED, WDCD, PMCD and EPS}

$\mathrm{HO}_{1}$ : EPED does not have significant impact on EPS of listed non-financial companies.

Based on the regression result, EPED is found to be significantly impacting on EPS. Hence, the null hypothesis is rejected and the hypothesis that there is a significant relationship between EPED and EPS is accepted.

H02: WDCD does not have significant impact on EPS of listed non-financial companies.

Based on the regression result, WDCD is found to be significantly impacting on EPS. Hence, the null hypothesis is rejected and the hypothesis that there is a significant relationship between WDCD and EPS stands.

H03: PMCD does not have significant impact on EPS of listed non-financial companies.

Based on the regression result, PMCD is found to be significantly impacting on EPS. Hence, the null hypothesis is rejected and the hypothesis that there is a significant relationship between PMCD and EPS is accepted.

Regression Result on EPED, WDCD, PMCD and TQ

Table 4.5 presents the regression OLS fixed effect result of (Model II).

\begin{tabular}{|c|c|c|c|c|}
\hline Variables & Coefficients & $\mathbf{t}$ & & $p>/ t /$ \\
\hline $\begin{array}{l}\text { EPED } \\
\end{array}$ & -0.0321851 & -1.40 & & 0.301 \\
\hline WDCD & -0.0332522 & -0.70 & 0.486 & \\
\hline PMCD & 0.1243784 & $2.56 * *$ & & 0.011 \\
\hline LEV & 0.0046059 & 1.57 & & 0.117 \\
\hline BSIZE & -0.002579 & -0.22 & & 0.827 \\
\hline FSIZE & -0.1642961 & $-5.18 * * *$ & 0.000 & \\
\hline CONS & 2.183306 & -6.47 & & 0.000 \\
\hline R-squared: Within & 0.0713 & & & \\
\hline Between & 0.3676 & & & \\
\hline Overall & 0.2042 & & & \\
\hline P-Value & & & 0.000 & \\
\hline
\end{tabular}

Source: Generated by the researcher from the Annual Reports and Account of the sampled companies using STATA 16.0

NOTE: *,**,*** Indicates significant@ 10\%, 5\% and 1\% respectively

ECRTD-UK: https://www.eajournals.org/

Journal level DOI: https://doi.org/10.37745/ejaafr.2013 
The cumulative adjusted $\mathrm{R}^{2}$ is $20 \%(0.2042)$, which gives cumulative effect of all independents variables jointly on the dependent variable. This means that $20 \%$ of the variation in the Tobin's $\mathrm{Q}$ is caused by EPED, WDCD, PMCD, LEV, BSIZE and FSIZE while $80 \%$ of the variation in Tobin's $Q$ is caused by other factors not considered in the model of the study. This indicates that the model is fit and the explanatory variables are carefully selected considering the $\mathrm{p}$-value of 0.0000 .

Table 4.5 reveals that EPED and WDCD has a negative and insignificant impact on Tobin's Q while PMCD has a positive and significant impact on Tobin's Q at 5\% level of significance. This means that the more companies disclose EPED and WDCD, the lower the Tobin's Q of listed nonfinancial companies in Nigeria under the study period. The result of this study is in line with the second school of thought of ED and firm value that viewed ED as an increased cost and therefore reduces value. And the more non-financial companies in Nigeria discloses PMCD the higher the Tobin's Q, this tally with the general conventional wisdom that corporate social and environmental responsibility helps strengthening the relationship between the firm and the society in which it operates and lead to an increases in value in the long run. Evidence shows if EPED and WDCD increases by one unit, financial performance measured by Tobin's Q will decreases by 0.0321851 and 0.0332522 respectively and when PMCD increases by one unit, financial performance measured by Tobin's Q will increase by 0.1243784 .

On the other hand, the reason for documenting the positive relationship between PMCD and Tobin's Q may be as a result that when non-financial companies in Nigeria discloses information concerning PMCD aids in providing good relationship between the society and the company which in long run increases sales and trust and in the long run increases value of the firm. This finding is consistent with work of Nuzula (2019), Emmanuel, Elvis \& Abiola (2019), Polycarb, (2019), Okpala and Iredele, (2018), Ezeagba, et.al, (2017). The negative direction can be attributed to classical shareholder theory (Friedman 1962) which postulates that ED is attached with costs have a detrimental impact on firm profits. The finding contradicts the works of Yang, Wen \& Li (2020), Emeka, Nwezu \& Nwadiolor (2020), Lastiningsih \& Ermawati (2020), Wara, Magali \&Mohamed (2020),Iliemena (2020); Nguyen \& Tran (2019), Oti \& Geraldine (2018), Yahaya (2018) which in general showed that environmental disclosure has positive impact on financial performance. The positive direction of ED and Financial performance relation can be attributed to stakeholder theory (Freeman 2010) that posits the benefits of higher ED as improved employee morale, reduced legal and compliance cost, higher productivity and increases the value in the long run.

Leverage is found to have positive and insignificant impact on financial performance measured by Tobin's Q. This means that, the more the debt of the listed non-financial companies of Nigeria the higher the financial performance measured by Tobin's Q. The finding is consistent with the findings of Nwanna \& Glory, (2017), Abubakar, et.al, 2017 that documented positive relationship between leverage and financial performance means that higher debt will lead to a reduction in taxable income via interest Payments.

ECRTD-UK: https://www.eajournals.org/

Journal level DOI: https://doi.org/10.37745/ejaafr.2013 
Board size is found to have negative but insignificant impact on financial performance measured by Tobin's Q of listed non-financial companies in Nigeria. This implies that as board increases in size this would definitely affect financial performance negatively even though the relationship is insignificant. This implies that market perceives larger boards as in effective as they tend to be symbolic rather than being part of the management process. This is because having large size of the board may lead to slow decision making and also huge amount is required for maintaining the large board which will have dangerous impact on the value of listed non-financial companies in Nigeria. A similar result was found in the findings in Okpala and Iredele (2018) that higher expenses and poor communication in larger boards make smaller boards preferable for value creation. Nevertheless, Ojeka, et.al, (2014) found a positive relationship between board size and Tobin's Q. it can be deduced that the communication costs and time wasted is higher that the possible benefits from engaging an additional director on the board.

Firm size shows a negative and significant impact on TQ. The result of the study does not agree with the economies of scale theory that larger firm have the advantage of producing at a lower cost and consequently increases financial performance. The finding coincides to the findings of Emeka and Benjamin (2019) that documented a negative relationship between firm size and financial performance of listed non-financial firms in Nigeria. The differences in the findings may be as a result of variance in the methods of obtaining the firm size and the study period. The result is not in line with the study of Uwuigbe (2012); Emeka and Okeke, (2019) that documented a positive relationship between firm size and financial performance.

\section{Hypothesis Testing on EPED, WDCD, PMCD and TQ}

H04: EPED does not have significant impact on TQ of listed non-financial companies.

Based on the regression result, EPED is found not to be significantly impacting on TQ. Hence, the null hypothesis is accepted and the hypothesis that there is a significant relationship between EPED and EPS is rejected.

H05: WDCD does not have significant impact on TQ of listed non-financial companies.

Based on the regression result, WDCD is found not to be significantly impacting on TQ. Hence, the null hypothesis is accepted and the hypothesis that there is a significant relationship between WDCD and TQ is rejected.

H06: PMCD does not have significant impact on TQ of listed non-financial companies.

Based on the regression result, PMCD is found to be significantly impacting on TQ. Hence, the null hypothesis is rejected and the hypothesis that there is a significant relationship between PMCD and TQ is accepted.

\section{CONCLUSION AND RECOMMENDATIONS}

The study concludes that ED (EPED, PMCD) has a positive impact on EPS, while WDCD has a negative impact on EPS. EPED, WDCD has negative impact on TQ with the exception of PMCD having positive impact of listed non-financial companies during the period of 2013 to 2020.

ECRTD-UK: https://www.eajournals.org/

Journal level DOI: https://doi.org/10.37745/ejaafr.2013 
Based the on the findings of the study, the study recommends that the management of the listed non-financial companies should encourage sustainability and ED and create environmental committees to handle environmental issues such as EPED, WDCD and PMCD since it increases financial performance(EPS).The existence of such committee is relevant for monitoring and implementation of quality environmental information practices although, this might seem like a profit reducing decision in the short run, the benefits that will accrue to the firm far outweigh the cost in the long run.

The Management of listed non-financial companies should create awareness on the importance of EPED, WDCD, PMCD and the other benefit that can be derived by a company and investors as a result of engaging in environmental activities as this may create good relationship between the company and the environment and consequently will improve financial performance(TQ). And also professional accounting bodies in Nigeria like the ICAN and the ANAN should key into introducing environmental and sustainability reporting into their mandatory professional education programs as this is a contemporary issue in accounting development this will help accountants to be trained on environmental accounting and reporting.

\section{References}

Abubakar, A., A. (2017). Influence of Firms Attributes on Environmental Disclosure in Listed Brewery Companies in Nigeria, Research Journal of Finance and Accounting,8(21)2, 3135

Abubakar,A.A., Moses, S., \& Inuwa, M.B., (2017). Impact of Environmental Disclosure on Performance of Cement and Brewery Companies in Nigeria, Civil and Environmental Research Journal, 9(10), 40-46

Abdallah, A.S., (2018). Social and Environmental Accounting Effect on Companies' Profit an Empirical study of some companies in Erbil), Account and Financial Management Journal, 3 (7), 1621-1633

Adediran, S.A., \& Alade, S. O. (2013). The Impact of Environmental Accounting On Corporate Performance in Nigeria, European Journal of Business and Management,5(23)141-155

Adegbie, F.F., Ogidan, A.A., Siyanbola, T.T., \& Adebayo, S.A (2020). Environmental Accounting Practices and Share Value of Food and Beverages Manufacturing Companies Quoted in Nigeria, Journal of critical Reviews, 7(13), 1-9

Adekanmi, A. D., Adedoyin, R. A., \& Adewole, J. A. (2015). Determinants of SocioEnvironmental Reporting of Quoted Companies in Nigeria, Journal of Research in Business, Economics and Management, 4(4), 459-471

Agbiogwu, A. A. Ihendinihu, J. U., \& Okafor, M. C. (2016). Impact of Environmental and Social Costs on Performance of Nigerian Manufacturing Companies, International Journal of Economics and Finance, 8(9), 173-180

Amiolemen, O., O, Uwuigbe, U., Uwuigbe, O., R., Osiregbemhe, I., S., \&Opeyemi,A.(2018). Corporate Social environmental reporting and stock prices: an analysis of listed firms in Nigeria, Investment Management and Financial Innovations, 15(3), 318-328

ECRTD-UK: https://www.eajournals.org/

Journal level DOI: https://doi.org/10.37745/ejaafr.2013 
European Journal of Accounting, Auditing and Finance Research

Vol.10, No. 2, pp.31-51, 2022

Print ISSN: 2053-4086(Print),

Online ISSN: 2053-4094(Online)

Bassey, B. E., Effiok, S. O., \& Eton, O. E. (2013). The Impact of Environmental Accounting and Reporting on Organizational Performance of Selected Oil and Gas Companies in Nige Delta Region of Nigeria, Research Journal of Finance and Accounting, 4(3), 57-73

Dibia, N. O., \& Onwuchekwa, J. C. (2015). Determinants of Environmental Disclosures in Nigeria: A Case Study of Oil and Gas Companies, International Journal of Finance and Accounting, 4(3), 145-152

Dhar, S., \& Asharaful, M., (2021). Impact Environmental Accounting Practices on Financial Performance: Evidence from Banking Sector of Bangladesh, International Journal of Asian Business and Information Management, 12(1),24-42

Egbunike, A.M., \& Okoro, G.E., (2018). Does green accounting matters to profitability of Firms in Nigeria: A Canonical Assessment, Original scientific paper 20(1), 17-26

Emmanuel, O., G., Elvis, E. \& Abiola, T. (2019). Environmental accounting disclosure and Firm Value of industrial goods companies in Nigeria, Journal of Economics and Finance, 10(1), $07-27$

Emeka-Nwokeji,N.A\&Okeke, P.,C.,(2019). Corporate environmental disclosure and performance of quoted non-financial firms in Nigeria, Journal of accounting, business and social sciences, $1(2), 33-43$

Emeka-Nwokeji,N.A\&Benjamin, O.,C.,(2019). Sustainability disclosures and Market Value In Emerging Economy: Evidence from Nigeria, European Journal of Accounting, Auditing and Finance Research,7(3),1-19

Emeka-Nwokeji,N.A\&Okeke, P.,C.,(2019). corporate environmental disclosure and performance of quoted non-financial firms in Nigeria, Journal of accounting, business and social sciences, $1(2), 33-43$

Emeka, L., O., Nwezu,A.U., \&Nwadiolor, E.,O.,(2020). Effect of Social and Environmental Dislosures on Performance of Non-Financial Firms in Nigeria, Journal of Accounting and Financial Management 6(1), 40-58

Etim, E.,O.,Confidence, I.,J.,Umoffong,N.,j.,(2020). Financial Performance Determinants at the Nigerian Oil and Gas Sector, East African Scholars Journal of Economics, Business and Management,3(12),941-951

Eze, J. C., Nweze, A. U., \& Enekwe, C. I. (2016). The Effects of Environmental Accounting on a Developing Nation: Nigerian Experience, European Journal of Accounting, Auditing and Finance Research, 4(1)17-27

Ezejiofor, R. A., Racheal, J.C, \& Chigbo, B. E. (2016). Effect of Sustainability organizations, Environmental Cost Accounting on Financial Performance of Nigerian corporate International Journal of Scientific Research and Management, 4(8), 4536-4549

Ezeagba, C.E,Racheal, J.C \& Chiamaka, U.(2017). Environmental Accounting Disclosures and Financial Performance: A Study of selected Food and Beverage Companies in Nigeria (2006-2015) International Journal of Academic Research in Business and Social Sciences 7(9), 162-174

Global Reporting Initiative (2002). Sustainability Reporting Guidelines, Retrieved from http://globalreporting.org on 2nd October, 2018.

Igbekoyi, 0.E., Ogungbade, O.I., \&Olaleye, A., G (2021). Financial performance and

ECRTD-UK: https://www.eajournals.org/

Journal level DOI: https://doi.org/10.37745/ejaafr.2013 
European Journal of Accounting, Auditing and Finance Research

Vol.10, No. 2, pp.31-51, 2022

Print ISSN: 2053-4086(Print),

Online ISSN: 2053-4094(Online)

Environmental sustainability reporting practices of listed manufacturing companies' in Nigeria, Global journal of accounting, 7(1), 2021:15-24

Ijeoma, N.B., (2015). Evaluation of Companies' Environmental Practices in Nigeria, Social Basic Sciences Research Review, 3(7), 349-364

Iliemena, R., O., (2020). Environmental Accounting Practices and Corporate Performance: Study of Listed Oil and Gas Companies in Nigeria, European Journal of Business and Management, 12(22), 58-70

Ironkwe, U. \& Promise, O.A. (2016). Environmental Reporting in the Oil and Gas Industry in Nigeria, International Journal of Research in Business Studies and Management, 3(11), 121

Jat, R., B. (2006). The impact of Market Structure on Corporate Performance in Nigeria: A study of the Banking Industry Journal of Business Management 1(1)

Jeroh, E., \& Okoro, G. E. (2016). Effect of Environmental and Dismantling Costs on Firm Performance among Selected Oil and Gas Companies in Nigeria, Sahel Analyst: Journal of Management Sciences, 14(5), 14-26

Mohammad, S., D., Bala, A., and Hassan (2020). Determinants of corporate social and environmental disclosure in the Nigerian oil and gas industry; An empirical investigation, International Journal of Auditing and Accounting Studies, 2 (2), 2020: 129-153

Makori, D. M., \& Jagongo, A. (2013). Environmental Accounting and Firm Profitability: An Empirical Analysis of Selected Firms Listed in Bombay Stock Exchange, India. International Journal of Humanities and Social Science, 3(18), 248-256

Namakonzi, R., \& Inanga, E. (2014). Environmental Management Accounting and Environmental Management in Manufacturing Industries in Uganda, African Journal of Economic and Sustainable Development, 3(4), 288-329

Nguyen, L., S., \& Tran, M., D., (2019). Disclosure Levels of Environmental Accounting Information and Financial Performance: The case of Vietnam, Management sciences letters,9(1) 557-570

Nuzula, N., F. (2019). Does environmental cost affect japanese firms' performance? International Journal of Professional Business Review, 4 (1), 14-21

Nnaemeka, N. J., Lucy, O. U., \& Kevin, U. O. (2017). Effect of Sustainability Accounting And Reporting on Financial Performance of Firms in Nigeria Brewery Sector,European Journal of Business and Innovation Research, 5(1), 1-15

Nwaiwu, N.J. \& Oluka, N.O (2018). Environmental Cost Disclosure and Financial Academic Performance of Listed Oil and Gas Companies in Nigeria, International Journal of Advanced Research and Financial Management, 4(2)1-23

Nwanna, I., \& Glory, I., (2017). Effects of Financial Leverage on Firms's Performance: A Study of Nigerian Banks, international Journal of Recent Scientific Research,8(7),18554-18564

Oba, V., C \& Fodio, M., I. (2012). Board Characteristics and the Quality of Environmental Reporting in Nigeria, Journal of Accounting and Management, 2(2), 33-48

Oguaon, S., and Ekpulu, G., A., (2020). Environmental Reporting and Operational of Performance: A study of listed Manufacturing Companies in Nigeria, International Journal intellectual disclosure, 3(1), 1-17

ECRTD-UK: https://www.eajournals.org/

Journal level DOI: https://doi.org/10.37745/ejaafr.2013 
European Journal of Accounting, Auditing and Finance Research

Vol.10, No. 2, pp.31-51, 2022

Print ISSN: 2053-4086(Print),

Online ISSN: 2053-4094(Online)

Okafor, T.G. (2018). Environmental Costs Accounting and Reporting on Firm Financial Performance: A Survey of Quoted Nigerian Oil Companies. International Journal of Finance and Accounting, 7(1), 1-6

Okpala, O.P., \& Iredele, O.O. (2018). Corporate Social and Environmental Disclosures and Market Value of Listed Firms in Nigeria, Copernican Journal of Finance \& Accounting, 7(3), 928. http:// dx.doi.org/10.12775/CJFA.2018.013

Okoye A., E. \& Ngwakwe C., C. (2004). Environmental Accounting: A Convergence of Antecedent Divergence", Accountancy; Management Companion, Nigerian Accounting Association (NAA), Nigeria

Olayinka, A.O., \& Oluwamayowo, I.O., (2014). Corporate Environmental Disclosures and Market Value of Quoted Companies in Nigeria, The Business and Management Review, 5(3), 171184

Ong, T.T., Tho, H.S., Goh, H.H., Thai S.B. \& Teh B.H. (2016). The Relationship between Environmental Disclosure and Financial Performance of Public Listed Companies in Malaysia, International Business Management, 10(4), 461-467

Oti, P.A., \& Geraldine,B.M. (2018). Analysis of Environmental and Social Disclosure and Financial Performance of Selected Quoted Oil and Gas Companies in Nigeria, Journal of Accounting and Financial Management, 4 (2), 1-12

Pandey, I. (2005). Financial Management, New Delhi: Vikas Publishing House.

Pedron, A., P., Clea, M., C., \& Simon, D., (2021). Environmental disclosure effects on returns And market value of listed Brazilian Companies, Journal of Business Ethics, .1(3),1-15

Polycarb, S., U., (2019). Environmental Accounting and Financial Performance of Oil andGas Companies in Nigeria, Research Journal of Finance and Accounting, 10(10)1-11

Shuaibu, K., Muhammad,A. \& Isah,U.,(2019). Corporate Governance and Environmental

Information Disclosure of Listed Cement Companies in Nigeria, International Journal of Management and Commerce Innovations, 7, (1), 292-305

UNEP (2011). Beyond Rio+20 United Nations Conference on Sustainable Development Held in Brazil on 20-22 June, 2012

Uwuigbe,U., Egbide,B., \& Ayokunle,A.M,(2011). The Effect of Board Size and Board Composition on Firms Corporate Environmental Disclosure: A Study of Selected Firms in Nigeria, Acta universitatis danubius publication, 7(5),164-176

Wara, R., K., Magali,J., \& Mohamed, S.,(2020). Environmental Disclosure and Financial Performance of Firms in Kenya, Research Journal of Finance and Accounting, 11(14), 5263

Yahaya,O.,A.(2018). Environmental Reporting Practices and Financial Performance of Listed Environmentally Sensitive Firms in Nigeria, Journal of Environmental and Social Sciences, 24(2) $403-412$

ECRTD-UK: https://www.eajournals.org/

Journal level DOI: https://doi.org/10.37745/ejaafr.2013 